\title{
Efektivitas Training Fungsi Eksekutif Terkomputerisasi dalam Meningkatkan Kapasitas Fungsi Eksekutif dan Performa Akademik Matematika
}

\author{
The Effectiveness of Computerized Executive Function Training In \\ Improving Executive Function Capacity and Mathematics Performance
}

Isman Rahmani Yusron ${ }^{1}$, Sri Kusrohmaniah ${ }^{2}$

Fakultas Psikologi, Universitas Gadjah Mada

Submitted 6 Maret 2020

Accepted 28 Oktober 2020

Published 28 Oktober 2020

\begin{abstract}
The mathematics performance of Indonesian children was reported to be lower than expectation. There is an indication that executive function contributes to mathematics performance and achievement. This study aimed to test the effectiveness of computerized executive training to boost mathematics performance. Task paradigms namely n-back task, flanker task, go no/go task, numerical-estimation task, and stroop task were arranged into a set of training using OpenSesame ${ }^{\circledR}$ program. Experimental group $(n=32)$ was given 45 -minute training for 7 days as well as mathematics test in pretest and posttest phases. Control group was also given mathematics pretest and posttest without any treatment. T-test showed that there was a significant difference between pretest and posttest $(t=5.04, p<0.05)$ in experimental group. Meanwhile, the control group did not show difference in terms of pretest and posttest scores $(t=1.21, p>0.05)$. ANOVA result showed significant difference of executive function capacity in each session $(F=13.47, p<0.05)$ with the mean score improving. This means that computerized executive function training is effective in improving executive function capacity and mathematics performance.
\end{abstract}

Keywords: academic performance; executive function; executive function capacity; mathematics

Abstrak. Performa bermatematika anak-anak Indonesia, dilaporkan jauh di bawah dari harapan. Terdapat indikasi bahwa fungsi eksekutif berperan dalam performa dan prestasi matematika. Penelitian ini bertujuan menguji efektivitas penggunaan training terkomputerisasi yang mengadopsi paradigma pengukuran fungsi eksekutif, untuk mendongkrak performa bermatematika. Paradigma tugas seperti n-back task, flanker task, go no/go task, numerical-estimation task, dan stroop task, dirangkai menjadi suatu latihan melalui aplikasi OpenSesame®. Kelompok eksperimen $(n=32)$, diberikan 45 menit training selama tujuh hari, dan diberikan tes matematika pada pre dan posttest. Kemudian, dibandingkan dengan kelompok kontrol $(n=34)$ yang juga diberikan pretest dan posttest tanpa diberi perlakuan apapun. Hasil pengujian menunjukkan perbedaan rerata yang signifikan $(t=-5,04 ; p<0,05)$ pada kelompok eksperimen antara hasil pretest dan posttest. Sedangkan pada kelompok kontrol, tidak ada perbedaan signifikan $(t=-1,21 ; p>0,05)$. Hasil uji ANAVA terhadap skor kapasitas fungsi eksekutif setiap sesi menunjukkan perbedaan signifikan $(F=13,47 ; p<0,05)$, dengan plot rerata skor meningkat. Hasil ini menunjukkan bahwa training fungsi eksekutif terkomputerisasi efektif dalam meningkatkan kapasitas fungsi eksekutif dan performa akademik matematika.

Kata Kunci: fungsi eksekutif; kapasitas fungsi eksekutif; matematika; performa akademik 
Pada studi terbaru, seperti studi dari Research on Improving Systems of Education (RISE) pada 2018 menemukan, kemampuan matematika siswa di Indonesia berada di level rendah (Beatty, Berkhout, Bima, Coen, \& Suryadarma, 2018). Studi ini menemukan, siswa kelas 1 hanya memiliki probabilitas menjawab benar soal matematika hanya $22 \%$, dan pada kelas 12 probabilitasnya meningkat hanya hingga $43 \%$, atau peningkatan melalui proses pembelajaran selama 12 tahun rata-rata hanya meningkat $21 \%$ saja dalam matematika. Bahkan, pada studi tersebut ditemukan bahwa kemampuan matematika siswa pada tahun 2014, lebih rendah daripada tahun 2000 pada setiap jenjang (Beatty et al., 2018).

Fakta hasil studi di atas, menjadi sebuah fenomena yang penting untuk dipecahkan, terutama mengenai usaha bagaimana mengakselerasi kemampuan akademik matematika siswa Indonesia. Berangkat dari hal tersebut, perlu upaya penelaahan mendalam mengenai faktor yang dapat mendorong peningkatan kemampuan matematika anak-anak Indonesia. Sehingga, berakar dari penelaahan tersebut akan menghasilkan solusi untuk menyelesaikan persoalan rendahnya kemampuan matematika anakanak Indonesia.

Performa individu dalam matematika, terkait erat dengan kapasitas fungsi eksekutif. Remaja dengan prestasi matematika rendah, berhubungan dengan kemampuan penggunaan strategi yang tidak efisien, seperti pada saat mengalkulasi solusi, yang hal ini melibatkan working memory dan fungsi eksekutif (Brown, 2018). Fungsi eksekutif, seperti goal setting, perencanaan dan pembuatan prioritas, pengorganisasian, memelihara dan memanipulasi informasi dalam working memory, pengalihan perhatian secara fleksibel, dan selfmonitoring, sangat penting untuk semua aspek dari performa akademik (Meltzer, 2010).

Fungsi eksekutif berpengaruh terhadap prestasi matematika dalam berbagai hal, misalnya pada saat proses penyelesaian masalah matematika, proses updating membantu dalam menahan informasi yang relevan dan pengambilan sebagian informasi mengenai hasil penyelesaian matematika dalam memori (Bull \& Lee, 2014). Selanjutnya menurut Bull dan Lee (2014), kemampuan kontrol inhibisi bisa menghentikan strategi yang tidak diperlukan pada saat penyelesaian masalah matematika, atau menahan penggunaan informasi dari masalah kata yang tidak relevan pada solusi matematika.

Selain itu, kemampuan shifting juga dapat membantu dalam beralih di antara beberapa operasi, strategi solusi, rentang kuantitas, notasi serta operasi antar tahap yang kompleks dalam berbagai tahap penyelesaian masalah (Bull \& Lee, 2014). Pada temuan penelitian lain, menyebutkan kapasitas working memory yang adekuat, merupakan komponen penting dalam perkembangan aritmetika, dan malah kapasitas ini muncul untuk menyokong manipulasi mental yang diperlukan untuk kalkulasi (Berch, Geary, \& Koepke, 2016).

Hasil penelitian Cragg, Keeble, Richardson, Roome dan Gilmore (2017) yang menginvestigasi pengaruh langsung serta tidak langsung fungsi eksekutif dalam prestasi matematika, menemukan bahwa 
fungsi eksekutif menjelaskan 34\% varians dari prestasi matematika, $12 \%$ varians dari pengetahuan faktual, $15 \%$ varians dalam skill prosedural, dan 5\% varians dalam pemahaman konseptual. Pada penelitian ini ditemukan bahwa salah satu elemen dari fungsi eksekutif yakni keterampilan working memory, berhubungan dengan prestasi matematika dan juga pada komponen pengetahuan faktual skill aritmatika, pemahaman konseptual dan keterampilan prosedural. Temuan ini memberikan gambaran bagaimana peran fungsi eksekutif dalam memfasilitasi individu dalam mencapai target prestasi akademik.

Fungsi eksekutif dapat dilatih dan dapat ditingkatkan tak terbatas pada setiap usia, meski mungkin menggunakan pendekatan yang berbeda, fungsi eksekutif dapat ditingkatkan melalui latihan dan praktik (Diamond, 2013). Terkait hal itu, premis tersebut juga dikonfirmasi oleh hasil meta analisis yang dilakukan oleh Mowszowski, Lampit, Walton, dan Naismith (2016) yang meninjau secara sistematis mengenai penggunaan strategi training berbasis kognitif untuk meningkatkan fungsi eksekutif pada subjek usia lanjut ( $N=4120 ; M=>50$ tahun). Pada temuan mereka disebutkan, 11 dari 13 percobaan yang dilakukan dilaporkan menghasilkan peningkatan fungsi eksekutif yang signifikan, dengan size effect yang moderat (Mowszowski et al., 2016). Bahkan pada penelitian lain, seperti penelitian Law, Fong, dan Yau (2018) yang memberikan program latihan fungsional untuk meningkatkan fungsi eksekutif pada subjek 60 ke atas dengan ganguan kognitif ringan, menunjukkan hasil fungsi eksekutif yang meningkat signifikan.

Selaras hal tersebut, pada penelitian lain hasil meta-analisis menyebutkan strategi pengembangan fungsi eksekutif termasuk beberapa permainan terkomputerisasi, usaha training secara langsung maupun pendekatan kurikulum, mengindikasikan bahwa fungsi eksekutif dapat ditingkatkan dan sangat penting outcome-nya diperlukan untuk mendukung optimalisasi belajar dan penyelesaian masalah (Clements, Sarama, \& Germeroth, 2016). Berdasarkan hal tersebut, sangat memungkinkan untuk dilakukannya sebuah upaya untuk meningkatkan kapasitas fungsi eksekutif yang pada penelitian terdahulu disebutkan terkait erat dengan kemampuan matematika individu. Geary (2017) menyatakan, semakin besar kapasitas fungsi eksekutif terutama working memory, semakin baik belajar matematikanya. Kapasitas fungsi eksekutif, dalam hal ini adalah hasil skor yang dikalkulasi dengan merata-ratakan z-skor dari masing-masing pengukuran aspek fungsi eksekutif (Case et al., 2017).

Terkait dengan peningkatan kapasitas fungsi eksekutif ini, sebuah penelitian dilakukan oleh Homer, Plass, Raffaele, Ober, \& Ali (2018) yang mencoba meningkatkan kemampuan fungsi eksekutif melalui permainan video game. Terhadap subjek usia sekolah menengah atas, mereka diminta memainkan Alien Game, permainan digital yang dikembangkan untuk melatih sub kemampuan dari fungsi eksekutif yakni peralihan perhatian (shifting), selama 20 menit setiap minggu selama enam minggu. Temuan dalam penelitian ini menunjukkan 
bahwa Alien Game ini memiliki pengaruh signifikan terhadap peningkatan fungsi eksekutif. Peneliti berargumentasi, bahwa game digital dapat menjadi alat yang efektif untuk melatih keterampilan kognitif ketika secara eksplisit dan teliti dirancang untuk meningkatkan kapasitas keterampilan kognitif tertentu (Homer et al., 2018).

Pada penelitian lainnya, Seperti dalam penelitian Salminen, Strobach, dan Schubert (2012) yang menggunakan dual nback task dan attentional blink task dalam paradigma yang sama selama 14 hari, dengan tujuan meningkatkan kapasitas Working memory dan efeknya terhadap fungsi eksekutif. Temuan penelitian menunjukkan pelatihan Working memory ini meningkatkan kemampuan reasoning, dan secara keseluruhan hasil penelitian mengonfirmasi temuan sebelumnya bahwa working memory dapat dilatih dan efek latihan ini dapat digeneralisir pada berbagai cabang fungsi eksekutif (Salminen et al., 2012).

Berdasarkan atas uraian yang telah dijelaskan, penelitian ini hendak menguji efektivitas training fungsi eksekutif terhadap kapasitas fungsi eksekutif dan peningkatan performa akademik matematika siswa. Strategi yang dialamatkan pada proses fungsi eksekusi dapat menjadi starting point dalam meningkatkan performa akademik (Meltzer dalam Goldstein \& Naglieri, 2014). Melalui penelitian ini, peneliti merancang training fungsi eksekutif melalui permainan digital kemudian menguji efektivitasnya dalam meningkatkan performa akademik matematika siswa. Pada penelitian ini, peneliti hendak menguji hipotesis penelitian yakni “Training Fungsi Eksekutif melalui permainan digital efektif meningkatkan performa akademik matematika".

\section{Metode}

\section{Desain penelitian}

Penelitian ini menggunakan pendekatan kuantitatif, dengan desain penelitian eksperimen The pretest and posttest control group design. Pada eksperimen ini, subjek di kelompokan untuk mendapatkan treatment atau kondisi alternatif dengan proses yang acak seperti lemparan koin atau tabel angka random (Shadish, Cook, \& Campbell, 2002). Variabel pada penelitian ini adalah Performa Akademik Matematika sebagai variabel terikat pertama, dan Kapasitas Fungsi Eksekutif sebagai variabel terikat kedua. Sedangkan, Variabel bebasnya adalah Training Fungsi Eksekutif, yang di digitalisasi melalui aplikasi OpenSesame ${ }^{\circledR}$.

\section{Partisipan penelitian}

Partisipan pada penelitian ini adalah sebanyak 66 siswa madrasah aliyah, yang terdiri dari 23 laki-laki dan 43 perempuan. Karakteristik subjek pada penelitian ini adalah: (1) berusia antara 15-17 tahun; (2) terbiasa menggunakan komputer; (3) tidak memiliki gangguan penglihatan yang parah; (4) tidak memiliki gangguan kognitif; (5) dominan menggunakan tangan kanan (right handed); (6) bersedia mengikuti rangkaian training hingga akhir sesi. Partisipan diberikan tes matematika sebagai pre-tes, dan di kelompokkan secara acak melalui bantuan aplikasi Microsoft Excel $^{\circledR}$, menjadi dua kelompok yakni kelompok eksperimen $(n=32)$ dan kelompok kontrol $(n=34)$. Kelompok eksperimen 
diberikan latihan Training Fungsi Eksekutif yang dioperasikan melalui aplikasi OpenSesame $^{\circledR}$ pada komputer di laboratorium Madrasah Aliyah Persis 31 Banjaran. Training Fungsi Eksekutif diberikan dengan durasi selama 45 menit setiap hari selama 7 hari.

\section{Instrumen pengukuran}

Alat ukur yang digunakan dalam penelitian ini terdiri dari tes matematika yang dipergunakan pada pretest dan posttest, dan juga aitem-aitem pada Training Fungsi Eksekutif melalui permainan secara terkomputerisasi. Aitem-aitem tes matematika digunakan untuk mengukur performa matematika subjek penelitian. Sedangkan, aitem pada Training Fungsi Eksekutif digunakan untuk mengukur kapasitas fungsi eksekutif. Skor kapasitas fungsi eksekutif adalah hasil kalkulasi dengan merata-rata kan skor-z pada setiap aspek pengukuran fungsi eksekutif (Case et al., 2017), yang pada penelitian ini hasil rata-rata skor-z nya di konversi menjadi TSkor $\{50+10(z)\}$.

Pada tes matematika, tes disusun dan divalidasi bersama guru matematika MA Persis 31 Banjaran, sdr.Candra Himawan,S.Pd. Soal Tes yang dibuat berjumlah 25 soal dengan durasi pengerjaan 45 menit. Muatan bahasan soal berisi sub materi penjumlahan $(n=6)$, Pecahan $(n=3)$, Bangun Ruang $(n=6)$, Grafik $(n=5)$ dan Statistik $(n=5)$. Hasil uji reliabilitas pada tes, menunjukkan koefisien Cronbach $\alpha=0,71$ dan rata-rata korelasi biserial Rbis $=0,414$ serta standar eror pengukuran sebesar SEM=1,99. Sebanyak 4 butir soal tes dieliminasi, kerena memiliki koefisien korelasi biserial yang sangat kecil
$(<0,2)$. Sehingga, butir tes yang disertakan pada pretes berjumlah 21 soal.

Sedangkan pada pengukuran kapasitas fungsi eksekutif, skor pengukuran diperoleh dari hasil akurasi respons Training Fungsi Eksekutif, berupa n-back task (1-back \& 2-back) yang mengukur working memory (Lezak, 2012), flanker task yang mengukur atensi selektif dan kontrol eksekutif (Voelcker-Rehage, Niemann, Hübner, Godde, \& Winneke, 2016), numerical estimation task yang mengukur working memory (Tan et al., 2007), Go-No-Go Task yang mengukur kontrol inhibisi dan monitor konflik (Lezak, 2012; Maruo, Sommer, \& Masaki, 2017; Sánchez-Kuhn et al., 2017), Stroop Task yang mengukur fleksibilitas kognitif (Jensen \& Rohwer Jr., 1966; Scarpina \& Tagini, 2017), dan dual nback task yang mengukur fokus atensi (Lilienthal, Tamez, Shelton, Myerson, \& Hale, 2013).

\section{Prosedur penelitian}

Seluruh partisipan yang bersedia berpartisipasi diberikan lembaran persetujuan (informed consent) untuk mengikuti penelitian. Kemudian, partisipan dikumpulkan untuk diberikan pretest berupa 21 butir tes matematika, yang telah disusun oleh guru matematika bersama peneliti. Pada tahap kedua, partisipan dikelompokkan pada dua kelompok yakni eksperimen dan kontrol secara acak dengan bantuan aplikasi Microsoft Excel ${ }^{\circledR}$, melalui formula =rand(). Masing-masing skor pretest kelompok berdistribusi normal, baik pada kelompok eksperimen $(Z=0,132$; $p>0,05)$ maupun kelompok kontrol $(Z=0,124 ; p>0,05)$. Rerata skor pre-tes kedua kelompok pun memiliki nilai setara ( $t=-$ 
0,264, $p>0,05)$ dan data bersifat homogen (Levene's Test $F=0,119 ; p>0,05$ ).

Terhadap kelompok eksperimen, mereka diundang untuk diberikan latihan Training Fungsi Eksekutif, setiap pukul 10.00 selama 45 menit setiap hari selama 7 hari. Training dilakukan di Laboratorium Komputer Madrasah Aliyah Persatuan Islam 31 Banjaran, disajikan melalui komputer dengan refresh rate $60 \mathrm{hz}$ dan tingkat kecerahan sebesar $70 \%$. Training diberikan melalui aplikasi Runtime OpenSesame $^{\circledR}$, dan respons partisipan dari papan tombol direkam secara otomatis oleh aplikasi tersebut. Pada tahap ketiga, kedua kelompok dikumpulkan kembali dan diberikan tes matematika yang sama seperti pada pre-tes, dan skor nya dianalisis sebagai data post-tes. Pelaksanaan tes matematika baik pada pre-tes maupun post-tes dilaksanakan dalam durasi 30 menit, menggunakan kertas dan pensil.

\section{Intervensi}

Training Fungsi Eksekutif yang digunakan dalam penelitian ini adalah adalah seperangkat latihan tugas terkomputerisasi dalam bentuk digital dengan menggunakan Aplikasi OpenSesame ${ }^{\circledR}$, yang berisi 6 tugas yakni Classic n-back Task, Go/No-Go Task, Numerical Estimation Task, Flanker Task, Stroop Task, dan Dual n-Back Task. Proses training ini, seperti halnya proses pengetesan berulang, yang diharapkan menghasilkan efek positif terhadap individu sesuai temuan Karpicke dan Roediger (2008) bahwa pengetesan berulang akan menghasilkan banyak efek positif dan meningkatkan retensi ingatan jangka panjang. Penjelasan selengkapnya disajikan pada Tabel 1 (hal. 193).
Analisis data

Analisis data penelitan yang pertama adalah melalui uji perbedaan mean berpasangan melalui uji-t related samples (Aron, Coups, \& Aron, 2013) untuk melihat bagaimana signifikansi perbedaan skor antara Pretest maupun Posttest pada kelompok Eksperimen dan Kelompok Kontrol. Selain itu, analisis data juga akan menggunakan teknik analisis ANAVA dengan mencari F-Ratio untuk melihat signifikansi perbedaan rerata skor Pretest dan Posttest kedua kelompok.

Kemudian, juga dilakukan analisis lanjutan dengan melihat Post-hoc analysis melalui metode Least Square Differences (LSD) Fisher untuk melihat perbedaan mean-nya. Analisis selanjutnya yang digunakan adalah dengan multivariate analysis of variance (MANOVA). Analisis MANOVA merupakan analisis statistik pada desain dengan lebih dari satu variabel dependen, melalui pengujian ini memungkinkan untuk menguji beberapa variabel dependen dalam satu set gabungan saat pengondisian variabel independen (Coolican, 2014). Analisis yang diterapkan adalah dengan Teknik General Linear Measures Repeated Measures (GLM-RM). Analisis ini untuk melihat perubahan skor akurasi respon subjek penelitan dari waktu ke waktu selama training berlangsung.

\section{Hasil}

Hasil pengambilan data pada Pretest, Posttest dan pengukuran Kapasitas Fungsi Eksekutif dapat dilihat pada Tabel 2. Pada analisis pertama, pengujian dilakukan 
Tabel 2.

Deskripsi Data Skor Hasil Pengukuran Variabel

\begin{tabular}{lllllll}
\hline Variabel & & Min & Maks & Rerata & SD & N \\
\hline \multirow{2}{*}{ Skor Performa Matematika } & Pretest & 31,23 & 52,87 & 44,35 & 5,05 & 66 \\
& Posttest & 32,64 & 72,44 & 49,65 & 9,94 & 66 \\
\hline \multirow{5}{*}{ Skor Kapasitas Fungsi } & T1 & 23,38 & 57,06 & 41,80 & 7,70 & 32 \\
Eksekutif & T2 & 34,19 & 59,31 & 47,24 & 6,91 & 32 \\
& T3 & 39,33 & 63,77 & 50,47 & 6,26 & 32 \\
& T4 & 36,33 & 62,26 & 50,90 & 6,41 & 32 \\
& T5 & 40,69 & 61,85 & 52,17 & 6,15 & 32 \\
& T6 & 39,95 & 62,51 & 53,16 & 6,15 & 32 \\
& T7 & 43,11 & 64,31 & 54,23 & 6,09 & 32 \\
\hline
\end{tabular}

dengan membandingkan mean antara Pretest dan Posttest tes matematika yang diberikan pada kelompok eksperimen dan kontrol. Berdasarkan hasil pengujian, pada pasangan pertama yang membandingkan antara skor Pretest dan Posttest pada kelompok eksperimen, menunjukkan hasil perbedaan yang signifikan $t=-5,044(p<0,05)$. Sedangkan pada hasil perbandingan rerata Pretest dan Posttest pada kelompok kontrol, menunjukkan signifikansi di bawah ambang kepercayaan 95\% yakni $t=-1,215$ $(p>0,05)$ yang berarti bahwa perbedaan rerata tidak signifikan. Berarti bahwa terdapat perbedaan rerata skor matematika antara Pretest dan Posttest pada kelompok eksperimen. Sebaliknya, pada kelompok kontrol, menunjukan adanya penerimaan hipotesis nihil dan menolak hipotesis alternatif. Hasil ini berarti bahwa tidak ada perbedaan rerata skor matematika antara Pretest dan Posttest pada kelompok kontrol. Bentuk perbedaan rerata skor Pretest dan Posttest pada kedua kelompok disajikan dalam Tabel 3.

ANAVA satu jalur dilakukan peneliti untuk menguji perbedaan pada skor 7 hari pengukuran kapasitas training fungsi eksekutif yang menunjukkan skor-skor akurasi respons training pada hari pertama hingga hari ke 7 perlakuan. Didapatkan gambaran bahwa terdapat perbedaan signifikan dari hari ke hari pada pengukuran kapasitas training fungsi eksekutif selama tujuh hari. Hasil uji-F menunjukkan koefisien $F=13,478(\mathrm{p}<0,05)$, , rerata mean antar kelompok pengukuran pada setiap sesinya berbeda secara signifikan. Hal ini memberikan indikasi yang penting bahwa Training Fungsi Eksekutif ini efektif meningkatkan kapasitas fungsi eksekutif.

Peningkatan skor kapasitas fungsi eksekutif secara nyata naik dengan signifikan, namun untuk melihat lebih jelas signifikansi peningkatan sebagai efek dari training maka dilakukan analisis lanjutan dari ANAVA tadi atau Test Post-Hoc untuk melihat bagaimana signifikansi peningkatan reratanya dalam interval kelompok pengukur Hasil tes post-hoc perbandingan skor setiap sesi melalui metode Least Square Differences (LSD) Fisher, tersaji pada Tabel 4.

Pada Tabel 4, terlihat data signifikansi perbedaan skor antar sesi Training Fungsi Eksekutif. Masing-masing perbandingan, memperlihatkan perbedaan mean nya, serta 
Tabel 3.

Statistik Rerata Pretest dan Posttest pada Kelompok Eksperimen dan Kontrol

\begin{tabular}{llllcc}
\hline & & Rerata & N & Std. Deviasi & Rerata Std. Eror \\
\hline Pasangan 1 & Pretest_eksperimen & 44,18 & 32 & 4,91 & 0,87 \\
& Posttest_eskperimen & 53,09 & 32 & 9,97 & 1,76 \\
\hline Pasangan 2 & Pretest_kontrol & 44,51 & 34 & 5,26 & 0,90 \\
& Posttest_kontrol & 46,42 & 34 & 8,90 & 1,52 \\
\hline
\end{tabular}

yang perbandingannya signifikan diberikan tanda bintang atau nilai signifikansinya $p<0,05$. Berdasarkan hasil pengujian di atas, terdapat komparasi yang bernilai signifikan antar sesinya, namun juga ada yang tidak signifikan meskipun meningkat. Contohnya dapat di lihat perbandingan antara Training 1 dengan Training 2, yang menunjukkan nilai signifikansi $\mathrm{p}<0,05$. Artinya skor pada training pertama dan kedua, peningkatan skor rerata nya signifikan, begitupun dari Training 2 ke Training 3 yang juga bernilai signifikan pada derajat kepercayaan 95\%. Akan tetapi, pada Training 3 menuju 4, perubahannya meningkat namun tidak signifikan $\quad(p>0,05)$ Begitupun perbandingan pada Training 4 ke Training 5 dan seterusnya, yang juga tidak signifikan perubahannya.

Untuk memastikan bahwa data skor pengukuran fungsi eksekutif tidak mengalami ceiling effect, hasil data skor dilakukan pengolahan deskriptif. Ceiling effect, adalah situasi dimana mayoritas nilai yang didapat suatu variabel mendekati batas atas dari pengukurannya, sehingga efek ini akan menghalangi analisis yang bermakna dari hasilnya (VandenBos, 2015).

Untuk memastikan hal ini, peneliti melihat skor kemiringan (skewness) data pada masing-masing waktu pengukuran (lihat Tabel), karena untuk melihat apakah terjadi ceiling effect pada data, dapat dilihat dari tingkat kemiringan yang cenderung melebar ke kanan yang lebih besar daripada nol. Data kemiringan data hasil pengukuran memperlihatkan tingkat kemiringan yang tidak melewati angka nol. Sehingga dengan demikian, data hasil pengukuran ini terbebas dari kondisi ceilling effect.

Jika pada uji-F yang diperbandingkan adalah rerata skor kapasitas fungsi eksekutif, untuk meningkatkan presisi atau kecermatan pengukuran mengenai efek dari Training Fungsi Eksekutif ini, maka dilakukan analisis Repeated Measures, yang mengukur varians eror / residualnya (Howitt \& Cramer, 2017). Karena, menurut Howitt dan Cramer (2017) untuk melihat tren peningkatan pada setiap individu dapat secara sederhana dideduksi dari skor eror yang ditinggalkan (residualnya).

Hasil analisis data melalui teknik amatan ulang ini diperlihatkan pada

Tabel . Dasar interpretasi yang dapat digunakan adalah melihat dari koefisien yang berada pada baris GreenhouseGeisser. Hal ini dikarenakan data ini tidak memenuhi asumsi kesamaan varian menurut tes Mauchly's of Sphericity. Berdasarkan hal tersebut, dapat dilihat bahwa nilai pada pengujian amatan ulang menunjukkan koefisien $F=119,233(p<0,05)$. Hasil pengujian terhadap residu data skor kapasitas fungsi eksekutif ini berarti 
Tabel 4.

Hasil Uji Lanjut ANAVA Tes Post-hoc LSD pada Skor Kapasitas Fungsi Eksekutif Setiap Sesi Training

\begin{tabular}{lllllll}
\hline \multirow{2}{*}{ (I) HARI } & \multirow{2}{*}{ (J) HARI } & $\begin{array}{c}\text { Perbedaan Rerata } \\
\text { (I-J) }\end{array}$ & Standar Eror & Sig. & \multicolumn{2}{c}{ 95\% Interval Kepercayaan } \\
\cline { 6 - 7 } T1 & T2 & $-5,44229^{*}$ & 1,63809 &, 001 & $-8,6709$ & $-2,2137$ \\
& T3 & $-8,67691^{*}$ & 1,63809 &, 000 & $-11,9055$ & $-5,4483$ \\
& T4 & $-9,10248^{*}$ & 1,63809 &, 000 & $-12,3311$ & $-5,8739$ \\
& T5 & $-10,37141^{*}$ & 1,63809 &, 000 & $-13,6000$ & $-7,1428$ \\
& T6 & $-11,35844^{*}$ & 1,63809 &, 000 & $-14,5870$ & $-8,1298$ \\
& T7 & $-12,43342^{*}$ & 1,63809 &, 000 & $-15,6620$ & $-9,2048$ \\
\hline T2 & T3 & $-3,23462^{*}$ & 1,63809 &, 050 & $-6,4632$ &,- 0060 \\
& T4 & $-3,66020^{*}$ & 1,63809 &, 026 & $-6,8888$ &,- 4316 \\
& T5 & $-4,92912^{*}$ & 1,63809 &, 003 & $-8,1577$ & $-1,7005$ \\
& T6 & $-5,91615^{*}$ & 1,63809 &, 000 & $-9,1448$ & $-2,6875$ \\
& T7 & $-6,99113^{*}$ & 1,63809 &, 000 & $-10,2197$ & $-3,7625$ \\
\hline T3 & T4 &,- 42557 & 1,63809 &, 795 & $-3,6542$ & 2,8030 \\
& T5 & $-1,69450$ & 1,63809 &, 302 & $-4,9231$ & 1,5341 \\
& T6 & $-2,68152$ & 1,63809 &, 103 & $-5,9101$ &, 5471 \\
& T7 & $-3,75650^{*}$ & 1,63809 &, 023 & $-6,9851$ &,- 5279 \\
\hline T4 & T5 & $-1,26893$ & 1,63809 &, 439 & $-4,4975$ & 1,9597 \\
& T6 & $-2,25595$ & 1,63809 &, 170 & $-5,4846$ &, 9727 \\
& T7 & $-3,33093^{*}$ & 1,63809 &, 043 & $-6,5595$ &,- 1023 \\
\hline T5 & T6 &,- 98702 & 1,63809 &, 547 & $-4,2156$ & 2,2416 \\
& T7 & $-2,06200$ & 1,63809 &, 209 & $-5,2906$ & 1,1666 \\
\hline T6 & T7 & $-1,07498$ & 1,63809 &, 512 & $-4,3036$ & 2,1536 \\
\hline
\end{tabular}

*. Perbedaan rerata signifikan pada level 0.05

terdapat perbedaan yang signifikan peningkatan skor kapasitas fungsi eksekutif pada setiap sesi training.

Temuan ini menunjukkan bahwa efek training terhadap peningkatan fungsi eksekutif berdampak nyata pada variabel dependennya. Untuk lebih detail melihat tingkat signifikansi efek dari training ini, dapat dilihat hasil perbandingan antar mean pada setiap sesi training yang disajikan dalam Tabel 7.

Pada pengukuran amatan ulang di atas, dapat terlihat secara jelas dan lebih presisi tingkat signifikansi perubahan variabel dependen sebagai hasil dari perlakuan variabel dependen pada penelitian ini. Berdasarkan Tabel, hampir semua perbandingan antar sesi Training
Fungsi Eksekutif menghasilkan efek yang signifikan pada kapasitas fungsi eksekutifnya. Hanya pada perbandingan sesi Training 3 ke Training 4 saja yang menunjukkan peningkatannya tidak signifikan. Atau dengan kata lain, Training Fungsi Eksekutif ini terbukti berpengaruh pada meningkatnya kapasitas fungsi eksekutif individu.

Berbagai data temuan yang telah dijelaskan di atas, seluruhnya mengantarkan pada penerimaan hipotesis yang dirumuskan oleh peneliti. Hipotesis didukung oleh temuan hasil analisis t-test dan F-test yang telah diuraikan sebelumnya. Kekuatan dari kesimpulan hipotesis yang pertama ini diperkuat oleh 
Tabel 5.

Statistik Deskriptif Kemiringan Data Skor Kapasitas Fungsi Eksekutif Setiap Sesi

\begin{tabular}{lcccccccc}
\hline & $\mathbf{N}$ & Min & Maks & Rerata & Std. Deviasi & \multicolumn{2}{c}{ Varians } & \multicolumn{2}{c}{ Kemiringan } \\
\cline { 2 - 9 } & Statistik & Statistik & Statistik & Statistik & Statistik & \multicolumn{2}{c}{ Statistik Statistik Std. Error } \\
\hline T1 & 32 & 23,38 & 57,06 & 41,8019 & 7,70686 & 59,396 &,- 115 &, 414 \\
T2 & 32 & 34,19 & 59,31 & 47,2447 & 6,91355 & 47,797 &,- 071 &, 414 \\
T3 & 32 & 39,33 & 63,77 & 50,4794 & 6,26779 & 39,285 &, 139 &, 414 \\
T4 & 32 & 36,33 & 62,26 & 50,9041 & 6,41525 & 41,155 &,- 279 &, 414 \\
T5 & 32 & 40,69 & 61,85 & 52,1744 & 6,15877 & 37,930 &,- 088 &, 414 \\
T6 & 32 & 39,95 & 62,51 & 53,1609 & 6,15521 & 37,887 &,- 370 &, 414 \\
T7 & 32 & 43,11 & 64,31 & 54,2359 & 6,09021 & 37,091 &,- 226 &, 414 \\
\hline
\end{tabular}

$\mathrm{N}$ valid 32

temuan yang dihasilkan dari analisis akademik (Goldstein \& Naglieri, 2014). pengujian lanjutan.

Pendapat tersebut yang dijadikan dasar

Tabel 6.

Hasil Analisis Amatan Ulang pada Data Kapasitas Fungsi Eksekutif pada Setiap Sesi Training.

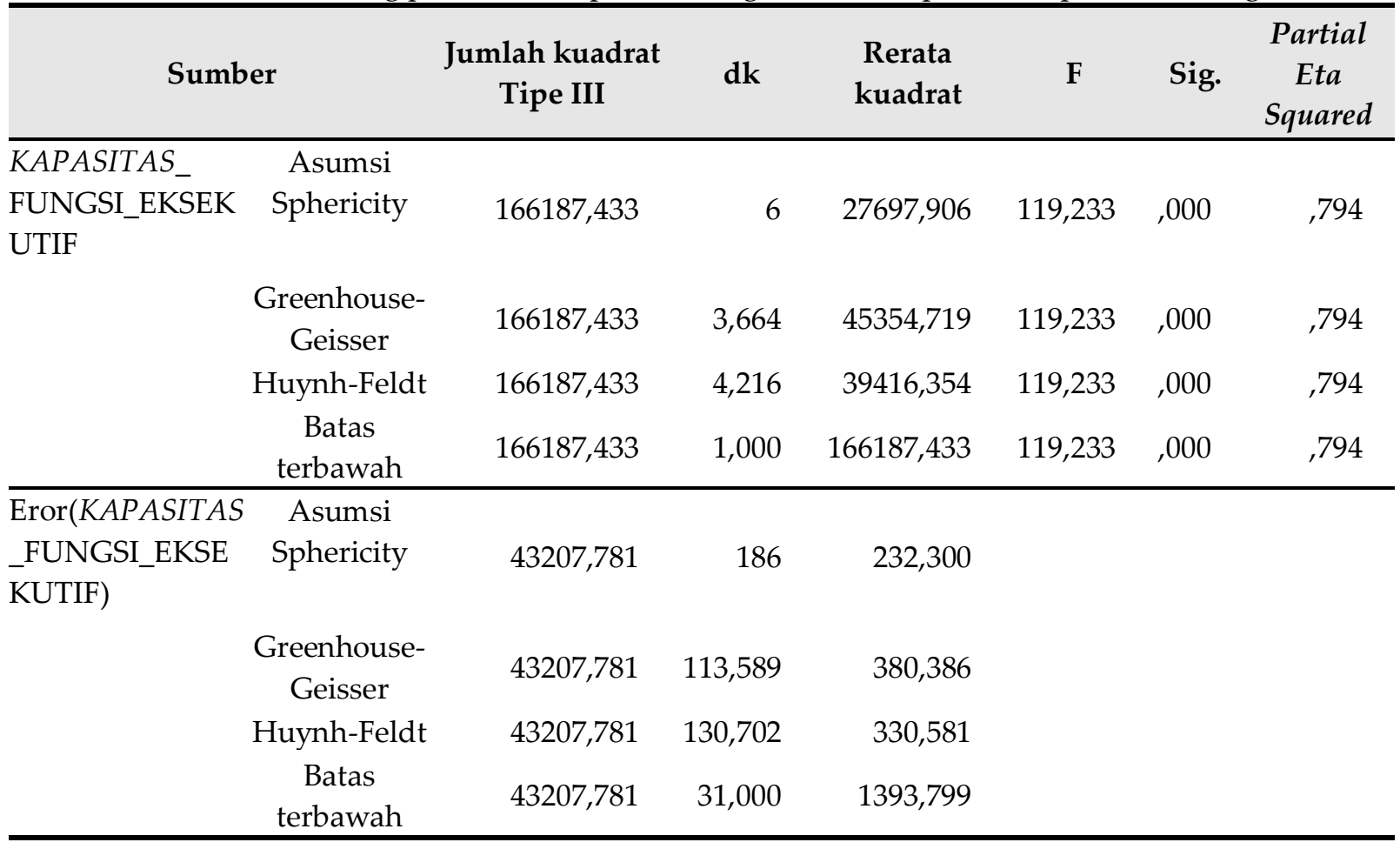

\section{Diskusi}

Temuan penelitian ini, selaras dengan pendapat Meltzer yang menyatakan bahwa strategi yang dialamatkan pada proses fungsi eksekutif dapat menjadi starting point dalam meningkatkan performa argumentasi peneliti pada penelitian ini, terbukti dengan hasil analisis statistik sebelum dan setelah perlakuan yang menunjukkan hasil yang mendukung. Melalui temuan ini, menghasilkan suatu insight baru mengenai keterkaitan erat antara fungsi eksekutif dengan performa 
Tabel 7.

Perbandingan Pasangan Mean Metode LSD Analisis Repeated Measures

\begin{tabular}{|c|c|c|c|c|c|c|}
\hline \multirow{2}{*}{$\begin{array}{c}\text { (I) } \\
\text { Kapasitas } \\
\text { Fungsi } \\
\text { Eksekutif }\end{array}$} & \multirow{2}{*}{$\begin{array}{c}(\mathrm{J}) \\
\text { Kapasitas } \\
\text { Fungsi } \\
\text { Eksekutif }\end{array}$} & \multirow{2}{*}{$\begin{array}{c}\text { Perbedaan rerata } \\
\text { (I-J) }\end{array}$} & \multirow{2}{*}{ Std. Eror } & \multirow{2}{*}{ Signifikansi } & \multicolumn{2}{|c|}{ 95\% Interval Kepercayaan } \\
\hline & & & & & Batas Bawah & Batas Bawah \\
\hline \multirow[t]{6}{*}{$\overline{1}$} & 2 & $-5,443^{*}$ & ,556 & 000 & $-6,577$ & $-4,309$ \\
\hline & 3 & $-8,678^{*}$ &, 516 & 000 & $-9,730$ & $-7,625$ \\
\hline & 4 & $-9,102^{*}$ & 718 & ,000 & $-10,566$ & $-7,639$ \\
\hline & 5 & $-10,373^{*}$ & ,776 & 000 & $-11,956$ & $-8,789$ \\
\hline & 6 & $-11,359^{*}$ & ,720 & 000 & $-12,827$ & $-9,891$ \\
\hline & 7 & $-12,434^{*}$ & ,765 &, 000 & $-13,995$ & $-10,873$ \\
\hline \multirow[t]{5}{*}{2} & 3 & $-3,235^{*}$ & 386 & 000 & $-4,022$ & $-2,447$ \\
\hline & 4 & $-3,659^{*}$ & ,487 & 000 & $-4,652$ & $-2,667$ \\
\hline & 5 & $-4,930^{*}$ & 633 & 000 & $-6,220$ & $-3,639$ \\
\hline & 6 & $-5,916^{*}$ & 607 & ,000 & $-7,154$ & $-4,679$ \\
\hline & 7 & $-6,991^{*}$ & 626 &, 000 & $-8,268$ & $-5,715$ \\
\hline \multirow[t]{4}{*}{$\overline{3}$} & 4 &,- 425 & 413 & 312 & $-1,267$ & ,417 \\
\hline & 5 & $-1,695^{*}$ & ,528 & 003 & $-2,773$ & -617 \\
\hline & 6 & $-2,682^{*}$ & ,540 & ,000 & $-3,782$ & $-1,581$ \\
\hline & 7 & $-3,757^{*}$ &, 558 & ,000 & $-4,895$ & $-2,618$ \\
\hline \multirow[t]{3}{*}{$\overline{4}$} & 5 & $-1,270^{*}$ & ,579 & ,036 & $-2,450$ &,- 090 \\
\hline & 6 & $-2,257^{*}$ & ,565 & ,000 & $-3,409$ & $-1,104$ \\
\hline & 7 & $-3,332^{*}$ & ,615 & ,000 & $-4,587$ & $-2,077$ \\
\hline \multirow[t]{2}{*}{5} & 6 &,$- 987^{*}$ & ,410 & ,022 & $-1,822$ &,- 151 \\
\hline & 7 & $-2,062^{*}$ & 553 & 001 & $-3,190$ &,- 933 \\
\hline 6 & 7 & $-1,075^{*}$ & ,418 & ,015 & $-1,928$ &,- 222 \\
\hline
\end{tabular}

akademik matematika. Meskipun pada temuan penelitian sebelumnya pun telah ditemui fakta penelitian, dimana kapasitas working memory yang merupakan salah satu elemen fungsi eksekutif, memprediksi kemampuan akademik matematika dan kompetensi penyelesaian masalah eksplisit (Geary et al., 2017). Begitupun dalam penelitian lainnya, yang menyimpulkan bahwa elemen fungsi eksekutif terutama working memory memainkan peranan langsung pada prestasi matematika (Cragg et al., 2017). Fungsi eksekutif, seperti perencanaan, kontrol, penyelesaian masalah dan atau penalaran memainkan peranan yang relevan ketika penyelesaian masalah numerik (Berch et al., 2016). Akan tetapi, pada rancangan intervensi pada penelitian ini, secara langsung menyasar berbagai keterampilan fungsi eksekutif yang tidak secara khusus hanya working memory saja. Meski demikian memang, performa akademik tidak hanya hasil peran working memory saja, namun juga melibatkan atensi, kontrol inhibisi dan keterampilan fungsi eksekutif lainnya, yang juga menjelaskan variabilitas yang substansial dalam prestasi matematika di sekolah (Clark, Pritchard, \& Woodward, 2010).

Lebih jauh, efektivitas Training Fungsi Eksekutif yang dibuktikan dalam penelitian 
ini, tidak menutup kemungkinan juga berpengaruh pada aspek performa akademik lainnya. Karena, berbagai elemen fungsi eksekutif yang disasar oleh intervensi pada penelitian ini juga sangat penting untuk semua aspek performa akademik (Meltzer, 2010). Pada sisi lain, fungsi eksekutif juga bukanlah merupakan entitas yang tetap sebagaimana halnya intelegensi, melainkan fungsi eksekutif ini dapat dilatih dan ditingkatkan kapasitasnya melalui latihan dan praktik (Diamond, 2013). Sehingga, Training Fungsi Eksekutif ini akan dapat berguna sebagai bagian dari intervensi dalam proses pendidikan di sekolah. Bentuk intervensi nya pun tidak memerlukan proses yang sangat panjang, karena sebagaimana temuan lainnya dalam penelitian ini, memperlihatkan setelah 4-5 kali training dilakukan, tingkat keterampilan fungsi eksekutif meskipun terus meningkat namun mulai semakin stabil dan tidak memperlihatkan progres peningkatan yang signifikan (lihat Error! Reference source not found.). Sehingga intervensi yang menyasar keterampilan fungsi eksekutif sebagaimana pada penelitian ini, menjadi cara sederhana yang dijadikan alat fungsional dalam proses akademik di persekolahan. Karena selama ini kapasitas fungsi eksekutif individu, tidak cukup mendapatkan perhatian secara langsung dalam proses pendidikan. Sebagai hasilnya, terdapat kesenjangan yang besar yang memisahkan antara keterampilan dan strategi yang diajarkan di sekolah dengan yang berasal dari kebutuhan proses fungsi eksekutif (Meltzer, 2007).

Terkait dengan keberfungsian alat Training Fungsi Eksekutif yang dirancang pada penelitian ini juga, telah dibuktikan cukup ajeg. Selain telah dapat membuktikan fungsinya untuk meningkatkan performa akademik matematika, alat ini juga cukup fungsional sebagai alat ukur kapasitas fungsi eksekutif hingga elemen-elemennya. Sebagai alat ukur, alat Training Fungsi Eksekutif ini terbukti memiliki reliabilitas yang memuaskan (lihat Error! Reference source not found.), meskipun masih memerlukan beberapa penyempurnaan seperti pada sub latihan No-Go Task yang memiliki koefisien reliabilitas yang belum memadai. Sub latihan No-Go ini bertujuan mengukur respon inhibisi atau keterampilan mengerem perilaku. Meski demikian, sub tes lainnya seperti Go-Task, Stroop dan sub latihan lainnya, pun mengukur dan melatihkan keterampilan inhibisi juga. Sehingga, alat training ini bisa dijadikan sebagai alat ukur yang cukup memadai untuk mengukur kapasitas fungsi eksekutif selain dijadikan alat training.

Selain efektif untuk meningkatkan performa matematika, sebagai alat latihan untuk meningkatkan kapasitas fungsi eksekutif, Training Fungsi Eksekutif juga terbukti efektif. Hal ini diperlihatkan pada hasil dari uji beda pada kelompok eksperimen antar interval waktu pada setiap sesinya. Hasil uji beda melalui teknik analisis ANAVA, didapatkan hasil bahwa dari waktu ke waktu selama 7 hari training dilakukan, kapasitas fungsi eksekutif terus meningkat signifikan. Data respon dari hari ke hari training, terus meningkat meskipun sebagaimana tergambar di Error! Reference source not found. pada hari ke4 dan selanjutnya peningkatan tidak terlalu signifikan. Namun, setidaknya, skor 
yang diasumsikan sebagai kapasitas fungsi eksekutif ini terus meningkat dan tidak menurun. Hal ini mengindikasikan bahwa efek training efektif dalam menyasar kapasitas fungsi eksekutif. Meski demikian, efektifivas peningkatan kapasitas fungsi eksekutif pada setiap sesinya terlihat dari hasil perbandingan residu pada setiap sesi, dimana melalui analisis Repeated Measures ANAVA memperlihatkan signifikansi peningkatan pada setiap sesi latihan.

Temuan penelitian ini relevan dengan penelitian sebelumnya meski berbeda, bahwa ketika secara eksplisit dan teliti di rancang untuk meningkatkan kapasitas keterampilan kognitif seperti fungsi eksekutif, pelatihan dengan bentuk permainan digital dapat berpengaruh secara signifikan (Homer et al., 2018). Meskipun, pada penelitian Homer dan koleganya, intervensi yang digunakan berbentuk Alien Game, yang sama sekali berbeda dengan training ini.

Adapun demikian, fakta statistik yang didapatkan pada studi saat ini, memperlihatkan kenyataan bahwa training yang dirancang, memberikan dampak signifikan pada meningkatnya keterampilan fungsi eksekutif. Kesimpulan ini juga didukung fakta pada temuan pertama dimana training ini berhasil meningkatkan performa akademik matematika yang pada penelitianpenelitian terdahulu ditemui berkorelasi dengan fungsi eksekutif (Berch et al., 2016; Geary et al., 2017).

\section{Kesimpulan}

Berdasarkan berbagai telaahan serta studi penelitian yang telah dilakukan peneliti, secara umum fakta penelitian mendukung hipotesis yang diajukan peneliti. Hasil penelitian yang dilakukan juga terbukti memperkuat literatur-literatur yang menjadi dasar argumentasi penelitian ini, juga relevan dan selaras dengan berbagai penelitian terdahulu dalam tema yang serupa. Berbagai hasil pengolahan data temuan penelitian mendukung kesimpulan bahwa Training Fungsi Eksekutif efektif dalam meningkatkan performa akademik matematika individu remaja usia sekolah menengah. Temuan lain yang juga didapatkan pada penelitian ini menyimpulkan bahwa Training Fungsi Eksekutif ini efektif dalam meningkatkan kapasitas fungsi eksekutif baik secara parsial maupun secara keseluruhan.

Penelitian yang menggunakan rancangan Training Fungsi Eksekutif yang dibuat secara seksama oleh peneliti melalui sajian permainan digital, berhasil menunjukkan performa efektivitas dalam memengaruhi seluruh variabel dependen, dalam suatu rangkaian eksperimen yang dilakukan pada studi ini. Hal ini menjadi temuan yang cukup memberi keyakinan bahwa ada alternatif intervensi yang lain, yang dapat diberikan kepada peserta didik untuk mendongkrak performa akademik di sekolah.

\section{Saran}

Perlu juga ada penelitian lebih lanjut dan lebih hati-hati agar keyakinan tentang efektifnya pemberian pelatihan yang menyasar fungsi eksekutif ini dapat diterima dan digeneralisasi secara lebih luas. Kendati demikian, temuan pada 
penelitian ini pula dapat menjadi sebuah pijakan awal untuk penelitian-penelitian selanjutnya yang serupa, agar fakta-fakta yang disimpulkan pada penelitian ini teruji dan disempurnakan oleh berbagai perspektif dan fakta temuan penelitian lainnya.

\section{Daftar Pustaka}

Aron, A., Coups, E. J., \& Aron, E. (2013). Statistics for psychology. Boston: Pearson.

Beatty, A., Berkhout, E., Bima, L., Coen, T., \& Suryadarma, D. (2018). Indonesia got schooled: 15 Years of rising enrollment and flat learning profiles. RISE Working Papers, 58.

Berch, D. B., Geary, D. C., \& Koepke, K. M.

(Ed.). (2016). Development of mathematical cognition: Neural substrates and genetic influences. Boston, MA: Academic Press.

Brown, R. D. (2018). Neuroscience of mathematical cognitive development: From infancy through emerging adulthood. Cham: Springer.

Bull, R., \& Lee, K. (2014). Executive functioning and mathematics achievement. Child Development Perspectives, 8(1), 36-41. doi: https://doi.org/10.1111/cdep.12059

Case, K., Guo, Y., Nixon, S. J., Muller, K., Huo, T., Prather, R., ... Shenkman, E. (2017). Exploring the role of executive functioning capacity in patient activation and health outcomes among Medicaid members with multiple comorbidities. Medical Care Research and Review, 76(4), 444-461. doi: https://doi.org/10.1177/107755871770 $\underline{9419}$

Clark, C. A. C., Pritchard, V. E., \& Woodward, L. J. (2010). Preschool executive functioning abilities predict early mathematics achievement. Developmental Psychology, 46(5), 1176-1191. doi: https://doi.org/10.1037/a0019672

Clements, D. H., Sarama, J., \& Germeroth, C. (2016). Learning executive function and early mathematics: Directions of causal relations. Early Childhood Research Quarterly, 36, 7990.

doi: https://doi.org/10.1016/j.ecresq.2015. $\underline{12.009}$

Coolican, H. (2014). Research methods and statistics in psychology. Hove: Routledge.

Cragg, L., Keeble, S., Richardson, S., Roome, H. E., \& Gilmore, C. (2017). Direct and indirect influences of executive functions on mathematics achievement. Cognition, 162, 12-26. doi:

https://doi.org/10.1016/j.cognition.20 17.01.014

Diamond, A. (2013). Executive functions. Annual Review of Psychology, 64(1), 135-168. doi:

\section{https://doi.org/10.1146/annurev-} psych-113011-143750[

Geary, D. C., Berch, D. B., Ochsendorf, R., \& Mann Koepke, K. (Eds). (2017). Mathematical cognition and learning: Vol. 3. Acquisition of complex arithmetic skills and higher-order mathematics concepts. San Diego, CA: Academic Press is an imprint of Elsevier. 
Goldstein, S., \& Naglieri, J. A. (Ed.). (2014). Handbook of executive functioning. New York, NY: Springer.

Homer, B. D., Plass, J. L., Raffaele, C., Ober, T. M., \& Ali, A. (2018). Improving high school students' executive functions through digital game play. Computers \& Education, 117, 50-58. doi:

https://doi.org/10.1016/j.compedu.20 17.09 .011

Howitt, D., \& Cramer, D. (2017). Understanding statistics in psychology with SPSS (Edisi ketujuh). New York: Pearson Education Limited.

Jensen, A. R., \& Rohwer Jr., W. D. (1966). The Stroop Color-Word Test: A review. Acta Psychologica, 25(1), 3693. doi: https://doi.org/10.1016/00016918(66)90004-7

Karpicke, J. D., \& Roediger, H. L. (2008). The critical importance of retrieval for learning. Science, 319(5865), 966968.

doi: https://doi.org/10.1126/science.11524 $\underline{08}$

Law, L. L., Fong, K. N., \& Yau, M. M. (2018). Can functional task exercise improve executive function and contribute to functional balance in older adults with mild cognitive impairment? A pilot study. British Journal of Occupational Therapy, 81(9), 495-502.

doi: https://doi.org/10.1177/030802261876 $\underline{3492}$

Lezak, M. D. (2012). Neuropsychological assessment. Oxford: Oxford University Press.

Lilienthal, L., Tamez, E., Shelton, J. T., Myerson, J., \& Hale, S. (2013). Dual n-back training increases the capacity of the focus of attention. Psychonomic Bulletin \& Review, 20(1), 135-141. doi: https://doi.org/10.3758/s13423-012$\underline{0335-6}$

Maruo, Y., Sommer, W., \& Masaki, H. (2017). The effect of monetary punishment on error evaluation in a Go/No-go task. International Journal of Psychophysiology, 120, 54-59. doi: https://doi.org/10.1016/j.ijpsycho.201 7.07.002

Meltzer, L. (2007). Executive function in education from theory to practice. New York: Guilford Press.

Meltzer, L. (2010). Promoting executive function in the classroom. New York: Guilford Publications.

Mowszowski, L., Lampit, A., Walton, C. C., \& Naismith, S. L. (2016). Strategybased cognitive training for improving executive functions in older adults: A systematic review. Neuropsychology Review, 26(3), 252270.

doi:

https://doi.org/10.1007/s11065-0169329-x

Salminen, T., Strobach, T., \& Schubert, T. (2012). On the impacts of working memory training on executive functioning. Frontiers in Human Neuroscience, 6, 166 . doi: https://doi.org/10.3389/fnhum.2012.0 $\underline{0166}$

Sánchez-Kuhn, A., León, J. J., Gôngora, K., Pérez-Fernández, C., SánchezSanted, F., Moreno, M., \& Flores, P. (2017). Go/No-Go task performance predicts differences in compulsivity but not in impulsivity personality 
traits. Psychiatry Research, 257, 270275.

doi:

https://doi.org/10.1016/j.psychres.20 17.07.064

Scarpina, F., \& Tagini, S. (2017). The Stroop Color and Word Test. Frontiers in Psychology, 8, 557. doi: https://doi.org/10.3389/fpsyg.2017.00 $\underline{557}$

Shadish, W. R., Cook, T. D., \& Campbell, D. T. (2002). Experimental and quasiexperimental designs for generalized causal inference. Boston, MA: Houghton, Mifflin and Company.

Tan, H.-Y., Chen, Q., Goldberg, T. E., Mattay, V. S., Meyer-Lindenberg, A., Weinberger, D. R., \& Callicott, J. H. (2007). Catechol-OMethyltransferase Val158Met modulation of prefrontal parietal striatal brain systems during arithmetic and temporal transformations in working memory. Journal of Neuroscience, 27(49), 13393-13401. doi: https://doi.org/10.1523/INEUROSCI. 4041-07.2007

VandenBos, G. R. (Ed.). (2015). APA dictionary of psychology (Edisi kedua). Worcester, MA: American Psychological Association.

Voelcker-Rehage, C., Niemann, C., Hübner, L., Godde, B., \& Winneke, A. H. (2016). Benefits of physical activity and fitness for lifelong cognitive and motor development: Brain and behavior. Dalam M. Raab, P. Wylleman, R. Seiler, A.-M. Elbe, \& A. Hatzigeorgiadis (Ed.), Sport and exercise psychology research: From theory to practice (hlm. 43-73). Cambridge, MA: Academic Press. 
Tabel 1.

Detil Training Fungsi Eksekutif Terkomputerisasi

\begin{tabular}{|c|c|}
\hline Tugas & Deskripsi Tugas \\
\hline Classic n-back Task & $\begin{array}{l}\text { Terdapat } 100 \text { kali stimulus yang disajikan. Stimulus yang muncul } \\
\text { berupa } 9 \text { kotak gambar kosong, kemudian muncul tampilan kotak } \\
\text { berwarna berisi huruf maupun angka sebagai distraktor, yang akan } \\
\text { muncul secara acak bergantian pada salah satu dari } 9 \text { kotak yang ada. }\end{array}$ \\
\hline Go/No-Go Task & $\begin{array}{l}\text { Partisipan disajikan gambar-gambar binatang dalam waktu } 1300 \text {, } \\
\text { milidetik, secara bergantian. Partisipan diminta untuk mengklik "spasi" } \\
\text { pada papan tombol, di setiap munculnya binatang yang merupakan } \\
\text { anggota kelompok burung-burungan (Aves) dan kategori barang } \\
\text { elektronik. }\end{array}$ \\
\hline Numerical & Responden diminta menaksir jumlah angka mana yang lebih besar \\
\hline Estimation Task & $\begin{array}{l}\text { atau lebih kecil, di kiri atau di kanan dengan menekan tombol kiri atau } \\
\text { kanan. Setelah } 100 \text { kemunculan stimulus pertama dengan durasi } \\
1000 \mathrm{~ms} \text {, akan dilanjutkan ke tugas selanjutnya yang sama namun } \\
\text { dengan durasi lebih cepat yakni } 500 \mathrm{~ms} \text {, yang muncul sebanyak } 100 \text { kali } \\
\text { stimulus }\end{array}$ \\
\hline Flanker Task & $\begin{array}{l}\text { Disajikan } 5 \text { buah deret gambar yang sama, dengan arah yang } \\
\text { sama kecuali gambar di tengah yang arahnya acak. Deret gambar } \\
\text { tersebut tersaji secara vertikal, horizontal maupun diagonal secara acak } \\
\text { bergantian. Partisipan diminta mengklik tombol arah sesuai dengan } \\
\text { arah gambar yang ada di tengah. Pada tugas kedua, partisipan akan } \\
\text { diminta menekan tombol sesuai arah gambar yang bukan di tengah } \\
\text { namun di gambar lainnya (reverse). }\end{array}$ \\
\hline Stroop Task & $\begin{array}{l}\text { Stimulus berupa kata warna-warna yang berwarna sama maupun } \\
\text { berbeda secara acak sebanyak } 100 \text { kali. Setiap stimulus disajikan selama } \\
1000 \text { milidetik. Partisipan diminta untuk mengklik tombol "A" atau "L", } \\
\text { dimana jika antara gambar dan warna sama klik "L" jika berbede klik } \\
\text { tombol "A". }\end{array}$ \\
\hline Dual n-Back Task & $\begin{array}{l}\text { Tersaji } 9 \text { lingkaran kosong, dimana secara bergantian akan muncul } \\
\text { gambar emotikon di tempat yang berbeda secara acak. Bersamaan } \\
\text { dengan hal tersebut, akan muncul kata-kata emosi di antara lingkaran } \\
\text { kosong. Responden diminta untuk mengklik tombol "A" setiap muncul } \\
\text { kata yang sama setelah jeda satu kemunculan kata lainnya dan } \\
\text { mengklik tombol "L", ketika gambar emotikon kembali ke posisi semula } \\
\text { setelah jeda kemunculan gambar di posisi lainnya. }\end{array}$ \\
\hline
\end{tabular}

